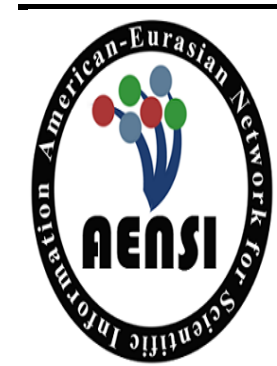

AUSTRALIAN JOURNAL OF BASIC AND APPLIED SCIENCES

ISSN:1991-8178

EISSN: 2309-8414

DOI: 10.22587/ajbas.2017.11.16.7

Journal home page: www.ajbasweb.com

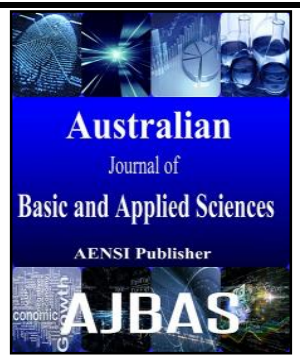

\title{
Performance of Soybean Culture In Function of Organic Fertilization With Poultry Bed Compared To Chemical Fertilization
}

${ }^{1}$ ClaudiaManteli, ${ }^{2}$ Rodrigo Jean Gonsalves, ${ }^{3}$ Alberto Ricardo Stefeni, ${ }^{4}$ Marciéli da Silva, ${ }^{5}$ AlexandreHack Porto, ${ }^{6}$ Cristiano Hossel, ${ }^{7}$ Gisely Correa de Moura

${ }^{I}$ Department of Agronomy, Federal Technological University of Paraná (UTFPR), PatoBranco, PR, 85503-390, Brazil.

${ }^{2}$ Agronomist engineer, Teaching Union of the Southwest of Paraná (Unisep), DoisVizinhos, PR, 85660-000, Brazil.

${ }^{3}$ Department of Agroecosystem, Federal Technological University of Paraná (UTFPR), DoisVizinhos, PR, 85660-000, Brazil.

${ }^{4}$ Department of Agronomy, Federal Technological University of Paraná (UTFPR), PatoBranco, PR, 85503-390, Brazil.

${ }^{5}$ Department of Agronomy, Federal Technological University of Paraná (UTFPR), PatoBranco, PR, 85503-390, Brazil.

${ }^{6}$ Department of Agronomy, Federal Technological University of Paraná (UTFPR), PatoBranco, PR, 85503-390, Brazil.

${ }^{7}$ Post doctorate by Federal Technological University of Paraná (UTFPR), PatoBranco, PR, 85503-390, Brazil.

\section{Address For Correspondence:}

Claudia Manteli, Department of Agronomy, Federal Technological University of Paraná (UTFPR), PatoBranco, PR, 85503-390, Brazil.

\section{A R T I CLE INFO}

\section{Article history:}

Received 12 October 2017

Accepted 22 December 2017

Available online 31 December 2017

Keywords:

Organic fertilizer, Agronomic characteristics, Glycine $\max$ Productivity.

\begin{abstract}
A B S T R A C T
The breeding and production of birds generate income and diversity of production in many rural properties, and has been increasing its share in the country's economy. However, the production process generates a large amount of waste, which in turn is characterized as an organic fertilizer with a high content of mineral nutrients, and that when well-managed, can be used as fertilizer crops. Soybean, considered the most important crop in the country, by production and for being a commodity, has the highest cost of production, fertilization, which is increased each year and decreasing the profit range of producers. The objective of this work was to evaluate the productive performance with the use of poultry bed in soybean as an alternative to chemical fertilization. The cultivar used was the BMX Vanguarda IPRO (IPRO 6160RSF) under the application of different doses of poultry bed previously moistened and covered by tarpaulin, previously composted in the field until the date of planting. The treatments consisted of: T1: Witness (free of fertilization); T2: Poultry bed in the concentration of 3.5 tha-1 (CA 3,5 t); T3: Poultry bed in the concentration of $7.0 \mathrm{t}$ ha-1 (CA 7.0 t); T4: Poultry bed in the concentration of 10,5 $\mathrm{t}$ ha-1 (CA 10,5 t); T5: Chemical fertilization (AQ) with NPK in formulation 02-18-18, applying $444.2 \mathrm{~kg}$ ha-1. The best result was obtained with the use of the CA $10.5 \mathrm{t}$ ha-1 treatment, with a higher mass of nodules, higher plant height and higher productivity. It was concluded that the poultry bed at the dose of $10.5 \mathrm{t}$ ha- 1 can replace the chemical fertilizer in the soybean crop in the productivity question, as well as for the other agronomic characteristics, as early as the first year of cultivation.
\end{abstract}

\section{INTRODUCTION}

Soybeans are considered the main culture of the Brazilian market, with a great emphasis on exports, currently characterized as the most cultivated crop in the country, with a harvested area of approximately 31.5 million ha, and an approximate production of 94, 28 million tons (ton) in the 2014/2015 harvest. With Paraná being the second state with the highest production with 14.78 million tons in a planted area of 5.017 million ha in the 2013/2014 harvest (CONAB, 2014).

Open Access Journal

Published BY AENSI Publication

(C) 2017 AENSI Publisher All rights reserved

This work is licensed under the Creative Commons Attribution International License (CC BY) http://creativecommons.org/licenses/by/4.0/

\section{(c) (1) \\ Open Access}

ToCite ThisArticle: Claudia Manteli, Rodrigo Jean Gonsalves, Alberto Ricardo Stefeni, Marciéli da Silva, Alexandre Hack Porto, Cristiano Hossel, Gisely Correa de Moura, Performance of soybean culture in function of organic fertilization with poultry bed compared to chemical fertilization. Aust. J. Basic \& Appl. Sci., 11(16): 49-55, 2017 
However, in order to reach this production, it was initially necessary to make expressive advances regarding the fertilization to be used, taking into account each producing region and the climatic conditions together (VALADÃO JÚNIOR et al., 2008).

In this context, high input investment is required to achieve high yields, where fertilizer generally covers the highest cost of production (FOLONI \& ROSOLEM, 2008).

Thus, it is necessary to search for new alternatives to replace or help chemical fertilizers in soybean nutrition, reducing the cost of production without compromising or limiting crop production and yield, and improving soil conditions, making production more sustainable.

Therefore, organic fertilizers are being used for this purpose, since, besides possessing compositional characteristics with considerable nutrient indexes, a destination for the use of such products is explored, exploring its potential as fertilizer (PADOVAN et al., 2002).

The poultry bed is considered an excellent organic fertilizer, having in its composition wood chips or rice straw, with bird droppings, feathers and food leftovers. This composition may vary with the amount and quality of the substrate used, however, the nutrient contents are around 24 to $40 \mathrm{~g} \mathrm{~kg} \mathrm{-1}$ of N, 20 to $35 \mathrm{~g} \mathrm{~kg}-1 \mathrm{of} \mathrm{P} 2 \mathrm{O}$, 18 to $35 \mathrm{~g} \mathrm{~kg}-1$ of $\mathrm{K} 2 \mathrm{O}$, and 65 to $90 \mathrm{~g} \mathrm{~kg}-1$ of dry matter (KONZEN \& ALVARENGA, 2000). Also containing important micronutrients for plants.

However, the use of poultry bed as an organic fertilizer, using large amounts of this material to supply the nutritional part of the plants, has to be taken into consideration the risk of environmental contamination if poorly managed (PANDOLFO et al., 2008).

However, new studies are needed with the use of poultry bed as an organic fertilizer. In this sense, the objective of this work was to evaluate the productive performance of poultry bed proportions in the soybean crop, as an alternative to chemical fertilization.

\section{MATERIAL AND METHODS}

The field experiment was conducted at Linha São Pedro, in the municipality of Ampére - PR, 2550'40'S latitude and 53029'12' O longitude, with elevation of $494 \mathrm{~m}$ (GOOGLE EARTH, 2015), belonging to the Southwest micro-region of the state of Paraná.

The predominant climate, according to the classification of Köppen (ALVARES et al., 2014), is characterized as mesothermic subtropical umid - Cfa. The precipitation of the period recorded by CooperativaCoopavelAgroindútria of Realeza - PR, located about 7,700 $\mathrm{m}$ in a straight line from the experimental site, presents an accumulation of $1267 \mathrm{~mm}$ for the period of October 15th, 2014 to March 11th, 2015 (Figure 1).

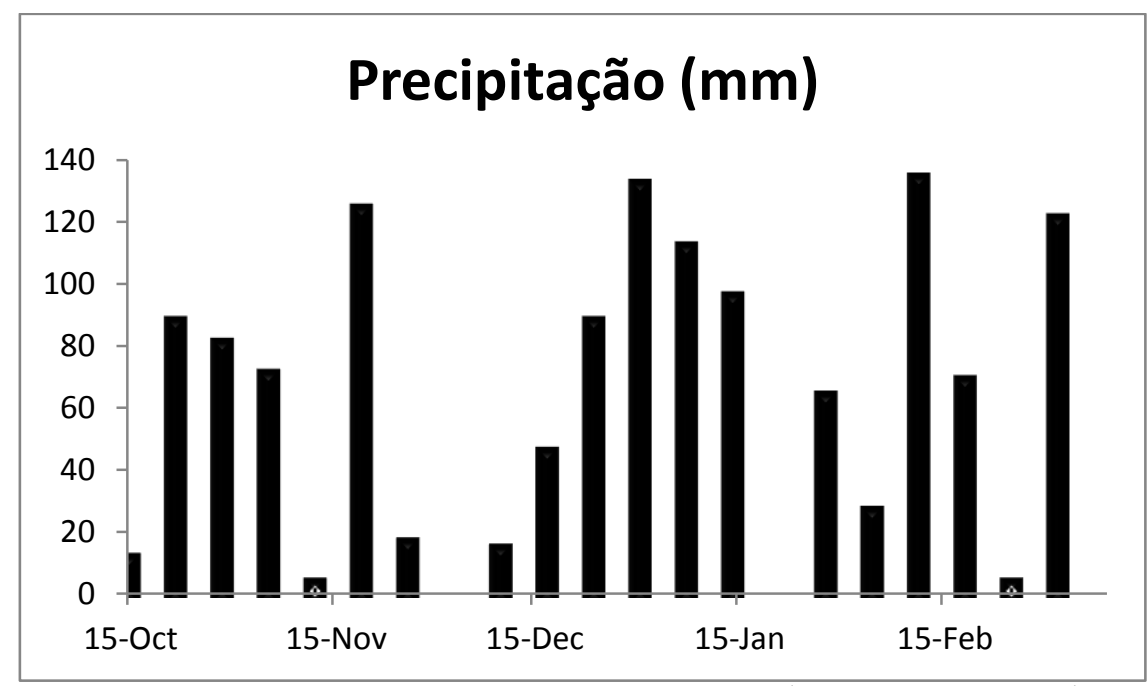

Fig. 1: Pluviometricprecipitacion in mm during the period of October $15^{\text {th }}, 2014$ to March $11^{\text {th }}, 2015$.

Source:CooperativaCoopavelAgroindustrial - Annual pluviometricprecipitacion. Adapted by the authors.

The soil of the experimental area is classified as Typic Red DistrophicLatosol (LVdf7) according to EMBRAPA (2006) and with implementation and use of the Direct Planting System for three years, being the fourth consecutive soybean crop, having as a sequence of Avenastrigosa, Glycine max (2011/2012), Avenasativa L. and Glycine max (2012/2013), wheat, Glycine max and Triticumaestivum L. (2013/2014). 
The nutritional status of the soil can be evidenced by the nutrient concentration of the soil, through soil analysis performed at depths of $0-10 \mathrm{~cm}$ and between $10-20 \mathrm{~cm}$. The soil analysis results can be observed in Table 1.

Tabela 1: Concentration of nutrients in the soil at the depths of $0-10$ and $10-20 \mathrm{~cm}$, by soil analysis.

\begin{tabular}{|c|c|c|c|c|c|c|c|c|}
\hline \multirow{2}{*}{ Depths $(\mathrm{cm})$} & $\mathrm{Ca}$ & $\mathrm{Mg}$ & $\mathrm{K}$ & $\mathrm{Al}$ & $\mathrm{H}+\mathrm{Al}$ & \multirow{2}{*}{$\begin{array}{l}\mathrm{MO} \\
\left(\mathrm{g} \mathrm{dm}^{-3}\right)\end{array}$} & \multirow{2}{*}{$\begin{array}{l}\mathrm{P} \\
\left(\mathrm{mg} \mathrm{dm}^{-3}\right)\end{array}$} & \multirow{2}{*}{$\mathrm{pH} \mathrm{CaCl}$} \\
\hline & \multicolumn{5}{|c|}{ 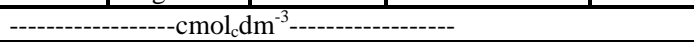 } & & & \\
\hline $0-10$ & 12.21 & 3.02 & 0.93 & 0.00 & 3.97 & 59.34 & 8.25 & 5.70 \\
\hline $10-20$ & 5.96 & 1.75 & 0.79 & 0.03 & 5.35 & 25.54 & 1.24 & 4.90 \\
\hline \multirow{2}{*}{ Depths $(\mathrm{cm})$} & $\mathrm{Fe}$ & $\mathrm{Mn}$ & $\mathrm{Cu}$ & $\mathrm{Zn}$ & \multicolumn{2}{|l|}{ CTC } & & $\mathrm{V} \%$ \\
\hline & \multicolumn{4}{|c|}{-------------mg dm ${ }^{-3}$----------- } & & & & \\
\hline $0-10$ & 14.84 & 68.59 & 4.26 & 3.25 & \multicolumn{2}{|l|}{20.13} & & 80.28 \\
\hline $10-20$ & 26.99 & 29.82 & 10.58 & 0.74 & \multicolumn{2}{|l|}{13.85} & & 61.37 \\
\hline
\end{tabular}

Source: The authors.

The poultry bed used for fertilization is the result of the productive process of laying birds, which remained for about a year in the establishment, without the removal of the bed. The bed was purchased at the end of May 2014, which was dampened and covered by canvas for the fermentation process.

The concentration of nutrients can be observed by analyzing the organic material (Table 2), where the values obtained from the sample analyzed by the Soloanalise Central de AnálisesLtda, from Cascavel - PR, were submitted to the planting of the crop, October 8th 2014.

Table 2: Chemical composition of the poultry bed used to compose the treatments

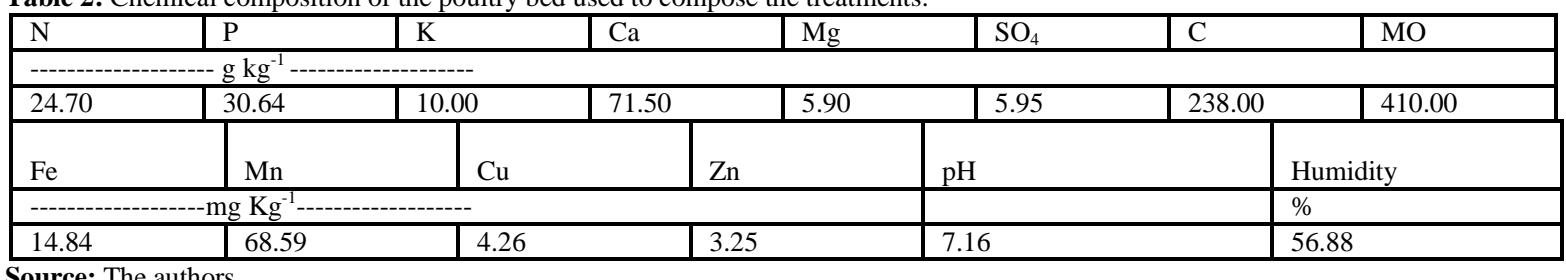

Source: The authors.

The cultivar used to conduct the experiment was the BMX Vanguarda IPRO (6160RSF IPRO)®. As an agronomic characteristic, the cultivar presents an early cycle, a population density of 250 to 350 thousand plants per ha-1. It belongs to the maturation group 6.0 and has an indeterminate growth habit, with a mean cycle of 132 days, a variety with high productive potential and demanding in soil fertility. It also has the Intacta RR2 PROTM® technology, which permits resistance to caterpillar attack.

The experimental design was a randomized block design with five treatments and four replications. Treatments consisted of: Witness: Fertilizer-free (TEST); Poultry bed in the proportion of $3.5 \mathrm{t}$ ha-1 (CA $3.5 \mathrm{t}$ ); Poultry bed in the proportion of $7.0 \mathrm{t}$ ha-1 (CA 7.0 t); Poultry bed in the proportion of 10,5 tha-1 (CA 10,5 t); and Chemical Fertilization (AQ) with formulation 02-18-18 (percentage of N, P, K per kg of fertilizer).

The plots consisted of nine planting lines with distances of $0.45 \mathrm{~m}$, by $4.5 \mathrm{~m}$ in length, and therefore a total area of $18,225 \mathrm{~m}^{2}$. The seven central lines were considered as useful area, being scattered $0.5 \mathrm{~m}$ from each end as a border, totalizing a useful area for analysis of the data of $9.45 \mathrm{~m}^{2}$. The blocks were divided by a planting line without any treatment, so that there was no interference from one treatment to another. Due to the distribution of the system in blocks, in addition to the area occupied by them, it was necessary to form a transit belt for spraying, which consisted of six planting lines. The scheme used, as well as the distribution of the treatments are shown according to the sketch (Figure 2).

Precisely on October 15th, 2014, the area was prepared, using the active ingredient Glyphosate ${ }^{\circledR}$ and Flumioxazin ${ }^{\circledR}$, a selective herbicide both for weed control.

The planting was carried out on October 22nd, 2014, under Direct Planting System, with 6.5 mm sieve soybean seeds, treated with the active ingredient (Fipronil + Piraclostrobin + ThiophanateMethylic $®)+$ polymer. The seed was yet inoculated with ADHERE $60 \AA$ peats, with a guarantee of 5 billion CFU g-1, until the expiration date, of Bradyrhizobiumelkani strains SEMIA 587® and SEMIA 5019®. The population used was 16 seeds per linear meter, approximately 350 thousand plants per hectare.

The chemical fertilization was carried out at the base, with the planting, with $444.2 \mathrm{~kg}$ ha- 1 of the formulated fertilizer 02-18-18. The application of the doses of poultry bed was performed on October 24th, 2014. After the equivalence of each dose per hectare to the area of the plot $(18.2 \mathrm{~m} 2)$, the organic fertilizer was weighed, with the aid of a digital scale (considering four digits after thecoma) and evenly distributed manually by the plot. 


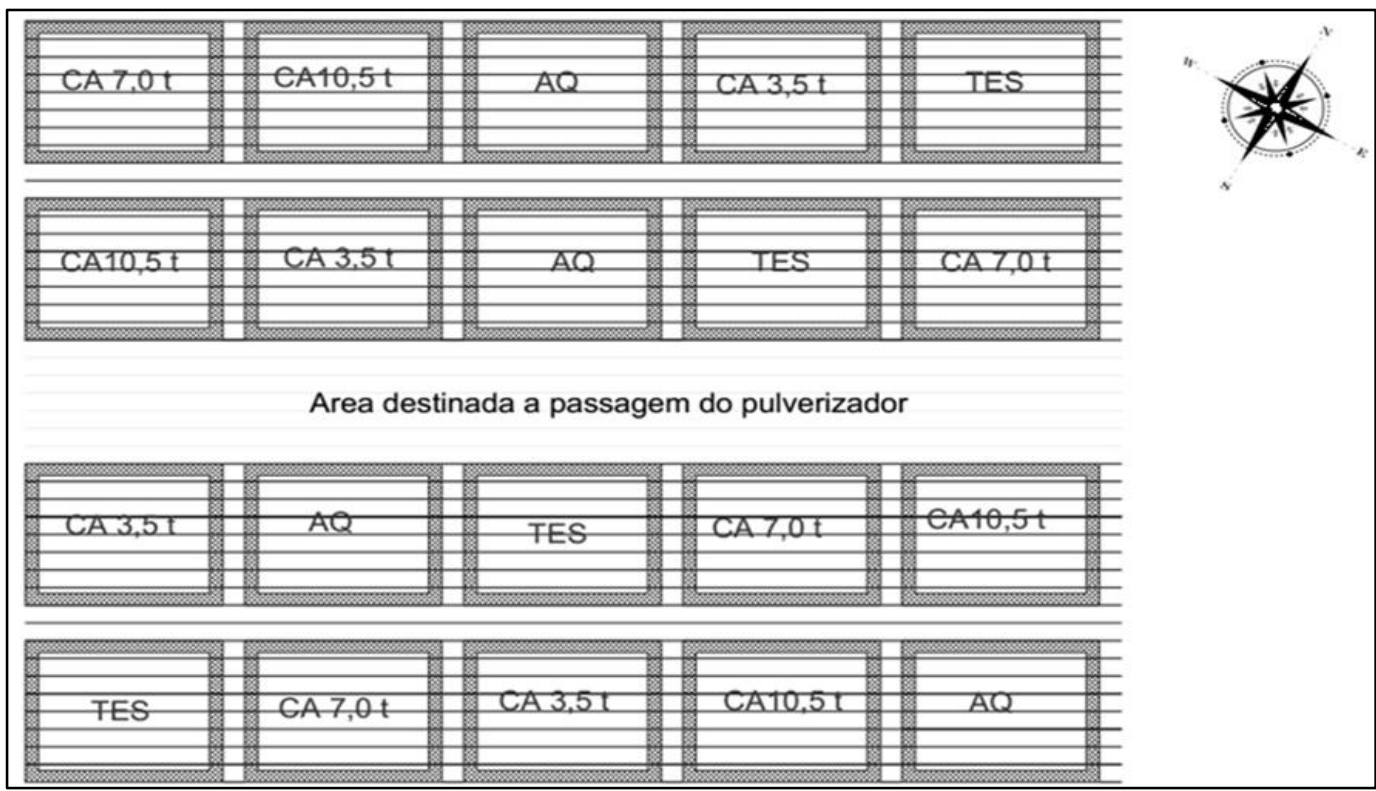

Fig. 2: Sketch of the experiment showing the arrangement of the plots carried out in the field, under a randomized block system.

The control of existing weeds was carried out with Glyphosate ${ }^{\circledR}$ in the acid equivalence of $540 \mathrm{~g} \mathrm{~L}-1$, at the dose of $2.5 \mathrm{~L}$ ha-1, considering that there were few weeds and infestations of easy control.

During the development of the crop, the monitoring of the experimental area was maintained, and pest and disease control was performed when identified and/or reaching the control level. No events were identified until the end of December.

However, preventive control of Phakopsorapachyrhizi, Nezaraviridula, Euschistusheros and Tetranychusurticae were carried out with three sprays during the crop cycle with intervals of 15 days after each application. For this purpose, the following products are used: FULLTEC® - ( $\mathrm{N}$ and P2O5); Fungicide: Piraclostrobin + Metconazol®; Insecticide: Imidacloprid®; Fungicide: Trifloxystrobin + Prothioconazole; Adjuvant: AUREO $®$ - (adjuvant methyl ester of soybean oil); Insecticide: Imidacloprid + Beta-Cyfluthrin $®$ and Acaricide: Abamectin ${ }^{\circledR}$. The doses used were followed the agronomic recipe and there was no mixing of active principle at the time of spraying.

At the R5 stage, an area of $0.5 \mathrm{~m}$ from the first planting line of the plot area of each plot was used for evaluation, where trenches with $0.5 \mathrm{~m}$ length and $0.5 \mathrm{~m}$ depth were excavated in order to maintain the largest number of intact roots and nodules. This procedure was performed after a three-day precipitation period, with a $128 \mathrm{~mm}$ accumulation, with high soil moisture, facilitating the removal of the roots. Once the plants were removed their roots were washed and the nodules removed, dried at room temperature and weighed in a digital scale, considering four digits after the comma.

At the reproductive stage R6, the period before senescence began, the height of plants was measured, using as sample ten plants of each plot, randomly choosen within the useful area, using as principle for measurement of the substrate (soil) to the apex of the apical meristem of the plant.

The same was done for height of insertion of the first pod, however, it was carried out in R8 to R9, when the plant is already apt to harvest and normally does not present any more changes in the height of pods, in this case, the principle of measurement was the insertion of the peduncle of the first pod into the stem.

The number of pods per plant and the number of grains per pod of the same ten plants in which the measurements of plant height and insertion of the first pod were carried out were counted. After harvesting the plots, 1000 grains of each plot were weighed.

Finally, an area of $7,875 \mathrm{~m}^{2}$ was allocated for productivity evaluation, considering the six planting lines of each plot, discarding the line where the trench was excavated, in addition to $0.5 \mathrm{~m}$ of the extremities.

The soybean plants, already dried, were harvested and threshed manually. The grains were cleaned, weighed and the moisture corrected to $13 \%$.

The data obtained in each of the variables were evaluated by the F-Test $(\alpha=0.05)$ and when significant submitted to the Scott Knott Test $(\alpha=0.05)$, with the aid of the statistical program Assistat (SILVA and AZEVEDO, 2002). 


\section{RESULTS AND DISCUSSION}

Treatment with CA $10.5 \mathrm{t} \mathrm{ha}^{-1}$ presented larger mass of nodules, followed by the witness treatment, which did not differ significantly by the Scott Knott test at 5\% significance, but differed from the CA $7.0 \mathrm{t} \mathrm{ha}^{-1}$ treatment. This effect is due to the greater amount of available organic matter, which consequently provides greater microbiological activity in the soil and interaction with the plants, approaching them and facilitating the symbiosis.

In Table 3, treatments with doses of poultry bed (CA), chemical fertilization (QF) and Witness (WIT) had significant effects on both nodule mass (NM) and plant height (PH), although it was not observed significant difference for insertion of the first pod (IFP). In the same way, despite the treatment CA $3.5 \mathrm{t} \mathrm{ha}^{-1}$ and chemical fertilization showed the lowest results, both did not differ among themselves.

Table 3: Averages of the results obtained with nodule mass $(\mathrm{g})$, insertion of the first pod $(\mathrm{cm})$ and height of plants (cm) in the soybean crop submitted to different amounts of fertilization with poultry litter and chemical fertilizer. Ampére - PR, 2015.

\begin{tabular}{|c|c|c|c|}
\hline Treatament & Nodules mass (g) & Insertion of the first pod $(\mathrm{cm})^{\mathrm{ns}}$ & Plant height $(\mathrm{cm})$ \\
\hline Witness & $9,00 \mathrm{a}$ & 23,38 & $102,32 \mathrm{c}$ \\
\hline CA 7,0 t ha ${ }^{-1}$ & $7,35 \mathrm{~b}$ & 23,82 & $110,46 \mathrm{~b}$ \\
\hline Chemical & $6,75 \mathrm{~b}$ & 22,96 & $110,62 \mathrm{~b}$ \\
\hline C.V. $(\%)$ & 7,29 & 8,85 & 2,81 \\
\hline
\end{tabular}

*Averages followed by the same letters in the column, do not differ from each other by the Scott Knott test ( $\alpha$ 0,05). NS: not significant results.

Studies performed by Ragagnin et al. (2013), using poultry bed at doses of 0, 1, 2, 4 and 8 t ha-1 compared to a mineral fertilization control, reinforces the results obtained, since they were similar in relation to the increase of mass of nodules found.

The lowest result with the nodules mass was obtained with mineral fertilization, which was already expected, since several studies have already shown that the addition of mineral nitrogen has a negative influence on the legume symbiosis, as demonstrated by Nogueira et al. (2010), where the mass of nodules was reduced as the nitrogen content of the soil was increased, making it detrimental to the biological fixation.

The nodules colonized by bacteria responsible for the fixation of atmospheric N2 together with the amount of $\mathrm{N}$ in the organic form of poultry bed ( $\square 259.35 \mathrm{~kg}$ ha- 1 , around $130 \mathrm{~kg}$ ha- 1 only in the first crop), provided greater availability of $\mathrm{N}$ to the plants, leading to greater cellular development, which reflected in the higher average plant height with the CA dose 10.5 t ha-1.

The height of plants was directly influenced positively regarding the availability of nutrients from the poultry bed, with an increase of $1.35 \mathrm{~cm}$ in average to each ton added, with a better performance of the dose CA $10.5 \mathrm{t}$ ha-1, followed by $93 \%$ lower performance for chemical fertilization and $33.33 \%$ lower for the CA $7.0 \mathrm{t}$ ha-1 dose. However, Aratani et al. (2008), saw that when $\mathrm{N}$ was available in mineral form, it did not obtain a significant statistical difference for the plant height and the first pod insertion variables.

In this sense, the effects of the different doses on the first pod insertion were also not observed, as this may be mainly related to being a structural factor, and has little influence on the environment, possibly related to genetic influences. The same fact occurred when using soil management techniques for this variable (CARVALHO et al., 2004).

The productivity, grains per plant (GP), pods per plant (PP) and grain yield (GY) indexes presented significant differences, and are presented in Table 4. It is evident the direct relationship between these variables and the applied doses due to the dependence of the plant on fertility and the supply of nutrients sufficiently.

Tabela 4: Averages of the results obtained in the indexes of productivity, grains per plant (GP), pods per plant (PP), thousand seed weight (TSW) and productivity $\left(\mathrm{kg} \mathrm{ha}^{-1}\right)$, of soybean crop submitted to different fertilizations with poultry bed and chemical fertilizer. Ampére - PR, 2015.

\begin{tabular}{|l|l|l|l|l|}
\hline Treatament & Grains per plant & \multicolumn{2}{l|}{ Pods per plant } & \multicolumn{2}{l|}{ TSW $(\mathrm{g})^{\mathrm{ns}}$} & Productivity $\left(\mathrm{kg}\right.$ ha $\left.^{-1}\right)$ \\
\hline Witness & $76,32 \mathrm{c}$ & $35,07 \mathrm{c}$ & 131,25 & $3601,49 \mathrm{~b}$ \\
\hline CA $3,5 \mathrm{t} \mathrm{ha}^{-1}$ & $97,17 \mathrm{~b}$ & $43,60 \mathrm{~b}$ & 133,25 & $3841,35 \mathrm{~b}$ \\
\hline CA $7,0 \mathrm{t} \mathrm{ha}^{-1}$ & $108,35 \mathrm{~b}$ & $48,12 \mathrm{~b}$ & 131,50 & $3978,98 \mathrm{~b}$ \\
\hline CA $10,5 \mathrm{t} \mathrm{ha}^{-1}$ & $136,67 \mathrm{a}$ & $59,42 \mathrm{a}$ & 136,50 & $4356,46 \mathrm{a}$ \\
\hline Chemical & $132,80 \mathrm{a}$ & $58,57 \mathrm{a}$ & 131,50 & $4253,57 \mathrm{a}$ \\
\hline C.V. $(\%)$ & 8,99 & 8,98 & 2.42 & 6,89 \\
\hline
\end{tabular}

*Averages followed by the same letters in the column, do not differ from each other by the Scott Knott test ( $\alpha$ 0,05). NS: not significant results. 
There were no significant differences for weight of one thousand seeds (WTS) in the evaluated treatments. In addition, the averages obtained are below the recommended $(165 \mathrm{~g})$ for this cultivar, due to the low humidity in which the grain was threshed.

The productivity increased during the increase of the applied doses, being the best performance due to the dose CA 10,5 tha 1 and the chemical fertilization resulting in 72,6 sc ha 1 and 70,88 sc ha 1, respectively. The absence of significant difference in these two treatments stems from the levels of nutrients provided by the dose of organic fertilizer and chemical fertilizer used. According to the Comissão de Química e Fertilidade do Solo (CQFS RS / SC, 2004) of the total applied only $50 \%$ of $\mathrm{N}$ and $80 \%$ of P2O5 would be available in the first crop, while the percentage of $\mathrm{K} 2 \mathrm{O}$ is not impacted by the mineralization rate of organic fertilizer and is fully available for crops in the first year of application. While in the chemical fertilization 02-18-18 (NPK) used, it would provide approximately $38 \%$ of $\mathrm{P} 2 \mathrm{O} 5$ and $24 \%$ of $\mathrm{K} 2 \mathrm{O}$ less than that provided by the organic fertilization in the abovementioned dose.

However, when compared to chemical fertilization, the treatment CA 7.0 t ha 1 presented 53.2\% more $\mathrm{P}_{2} \mathrm{O}_{5}$ and only $12.5 \%$ less $\mathrm{K}_{2} \mathrm{O}$, as well as the treatment CA 3.5 t ha 1 presented $8.9 \%$ more $\mathrm{P}_{2} \mathrm{O}_{5}$ and $56.2 \%$ less $\mathrm{K}_{2} \mathrm{O}$, and there may have been a limiting action on the part of the latter.

According to results by Carvalho et al. (2011), in the evaluation of agronomic characteristics of the soybean crop, there was a linear increase for plant height, one thousand grain mass, number of pods per plant and grain yield for the worked doses, and although lodging was observed for higher doses, the authors recommend the use of the poultry bed in agronomic and economic terms for the soybean crop. Carvalho et al. (2011), still reinforce the advantage of this technique when raising $\mathrm{K}$ and $\mathrm{S}$ contents in the soil.

In addition to the potential as a fertilizer, organic carbon molecules as well as the organic matter present benefits to the soil and consequently to the agricultural production, as they contribute to the increase of water retention and infiltration capacity, CTC and soil structural stability (CAETANO et al., 2013), as well as the residual effect that makes it possible to reduce fertilizer costs for the following crops.

\section{Conclusion:}

The poultry bed at the dose of $10.5 \mathrm{t}$ ha- 1 can replace the chemical fertilizer in the soybean crop having the productivity as focus, as well as the other agronomic characteristics, as early as in the first year of cultivation.

The increase of the doses of poultry bed favors nodulation, due to the increase of the organic matter and biological activity. However, the supply of mineral nitrogen impairs the formation of nodules and the biological fixation of $\mathrm{N}$. The height of plants also increases as there is an increase in the doses of poultry bed.

When well managed, the pultry bed presents itself as an alternative to the use of highly soluble fertilizers.

\section{Future Studies:}

Evaluations of Glycine max production indexes under seed inoculation performed directly in the planting groove.

\section{REFERENCES}

ALVARES, C.A., J.L. STAPE, P.C. SENTElHAS, J.L.M. GONÇALVES and G. SPAROVEK, 2013. Koppen's climate classification map for Brazil.MeteorologischeZeitschrift, 22(6): 711-728.

ARATANI, R.G., E. LAZARINI, R.R. MARQUES and C. BACKES, 2008. Adubação nitrogenada em soja na implantação do sistema plantio direto. BioscienceJournal, Uberlândia, 24(3): 31-38.

CAETANO, J.O., V.M. BENITES, G.P. SILVA, I.R. SILVA, R.L. ASSIS and A. CARGNELUTTI FILHO, 2013. Dinâmica da matéria orgânica de um NeossoloQuartzarênico de cerrado convertido para cultivo em sucessão de soja e milheto. Revista Brasileira Ciência do Solo, Viçosa, 37: 1245-55.

CARVALHO, M.A.C., M.L.F. ATHAYDE, R.P. SORATTO, M.C. ALVES and O. ARF, 2004. Soja em sucessão a adubos verdes no sistema de plantio direto e convencional em solo de Cerrado. Pesquisa Agropecuária Brasileira, Brasília, 39(11): 1141-1148.

CARVALHO, E.R., P.M. REZENDE, M.J.B. ANDRADE, A.M.A. PASSOS and J.A. OLIVEIRA, 2011. Fertilizante mineral e resíduo orgânico sobre características agronômicas da soja e nutrientes no solo. Revista Ciência Agronômica, Fortaleza, 42(4): 930-939.

CONAB - companhia nacional de abastecimento. Levantamento de safras. Acomp. safra bras. grãos, v. 2 safra 2014/15, n. $7 \quad$ - $\quad$ sétimo levantamento, abr. 2015 . Disponível em:〈http://www.conab.gov.br/olalacms/uploads/arquivos/15_04_10_09_22_05_boletim_graos_abril_2015.pdf> acesso em: $15 \mathrm{abr}, 2015$.

CQFS RS/SC - Comissão de química e fertilidade do solo, 2004. Manual de adubação e de calagem para os estados do Rio Grande do Sul e Santa Catarina. Porto Alegre, p: 394.

EMBRAPA - Empresa Brasileira de Pesquisa Agropecuária. Centro Nacional de Pesquisa de Solos. Sistema Brasileiro De Classificação De Solos, 2006. 2. ed. Rio de Janeiro: Embrapa Solos, p: 306. 
FOLONI, J.S.S. and C.A. ROSOLEM, 2008. Produtividade e acúmulo de potássio na soja em função da antecipação da adubação potássica no sistema plantio direto. Revista Brasileira de Ciência de Solo, Viçosa, 32: 1549-1561.

KONZEN, E.A. and R.C. ALVARENGA, 2000. Fertilidade de Solos: Adubação Orgânica. Embrapa Milho e Sorgo, Sistemas de Produção, Sete Lagoas.

LIMA, L.M. and J.F.S. MENEZES, 2014. Camas de frango tratadas com condicionadores na adubação da cultura do milho e da soja. Revista GeTec: Gestão, Tecnologia e Ciências, Monte Carmelo, 2: 6370.

NOGUEIRA, P.D.M., D.G.S. JÚNIOR and V.A. RAGAGNIN, 2010. Clorofila foliar e nodulação em soja adubada com nitrogênio em cobertura. Global Science And Technology, Rio Verde, 3(2).

PADOVAN, M.P., D.L. ALMEIDA, J.G.M. GUERRA, R.L.D. RIBEIRO and A. NDIAYE, 2002. Avaliação de cultivares de soja, sob manejo orgânico, para fins de adubação verde e produção de grãos. Pesquisa Agropecuária Brasileira, Brasília, 37(12): 1705-1710.

PANDOLFO, C.M., C.A. CERETTA, A.M. MASSIGNAM, M.D. VEIGA and C.L. MOREIRA, 2008. Análise ambiental do uso de fontes de nutrientes associadas a sistemas de manejo do solo. Revista Brasileira de Engenharia Agrícola Ambiental, Campina Grande, 12: 543-550.

RAGAGNIN, V.A., D.G. SENA JÚNIOR, D.S. DIAS and W.F. BRAGA, 2013. Growth and nodulation of soybean plants fertilized with poultry litter. Ciência e Agrotecnologia, Lavras, 37(1): 17-24.

SILVA, F.A.S. and C.A.V. AZEVEDO, 2002. Versão do programa computacional Assistat para o sistema operacional Windows. Revista Brasileira de Produtos Agroindustriais, Campina Grande, 4(1): 71-78.

VALADÃO JÚNIOR, D.D., A.C. BERGAMIN, L.R. VENTUROSO, J.A. SCHLINDWEIN, B. O. CARON and D. SCHMIDT, 2008. Adubação fosfatada na cultura da soja em Rondônia. Scientia Agraria, Curitiba, 9(3): 369-375. 